\title{
Mirosława Czerny
}

\section{THE SYSTEM OF CITIES IN LATIN AMERICA}

The present analysis of the city network in Latin America as a system is based on the definition of a system formulated by W. Sadowski: "a set of elements ordered in a certain way, related to each other and constituting an ensemble will be called a system". (W. Sadowski, 1978).

The sulject matter of a city system can be conceived of as a system of relations i.e. a configuration of elements forming a certain set (universum of relation system); its particular elements possess some characteristics and are related to each other in a paricular way. Any empirical city system can be described as:

$$
\mathrm{S}=\left\langle\mathrm{U}, \mathrm{X}_{1}, \ldots, \mathrm{X}_{\mathrm{n}}, \mathrm{R}_{\mathrm{n}}, \ldots, \mathrm{R}_{\mathrm{m}}, \alpha_{1}, \ldots, \alpha_{\mathrm{p}}\right\rangle
$$

where $U$ standis for a set comprising all the cities of Latin America, $\mathrm{X}_{1}, \mathrm{X}_{2}, \ldots, \mathrm{X}_{\mathrm{n}}$ represent the sub-ets of cities in particular regions, $R_{1}, R_{2}, \ldots, R_{m}$ represent relations between particular cities;

$\alpha_{1}, \alpha_{2} \ldots, \alpha_{p}$ represent certain elements of the system, i.e. distinguished cities.

The city network will qualify as a system if it is presented as a set of its activities (i.e. the set in a collective sense, according to J. Kmita), coupled with a certain internal relation, possessing respective characteristics occurring in relations among elements of the set.

$$
\mathrm{A}=\left(\mathrm{a}, \mathrm{F}_{1}, \ldots, \mathrm{F}_{\mathrm{n}}\right)
$$

$\mathrm{F}_{1}, \ldots, \mathrm{F}_{\mathrm{n}}$ are symbols quantifying characteristics, relationships or cor-relation, i.e. variables to be found in a research paradigm concerning phenomena of the city system. Therefore it is important to make a proper selection of the relation which should possess definite characteristics. It must be done in such a way so that the city network, forming a set of the cities, according to the adopted definition, should constitute a system. 
Some relations between the cities and between particular characteristics of those relations are well recognized and described in literature (see: K. Dziewoński, 1972; Z. Chojnicki, 1973, 1977, 1980; R. Domański, 1976, 1980, 1982) but not all internal relations which cccur in the set would amount to a system comprising all the elements of the set.

Conceptualization of a settlement system, including the system of cities, as an open system characterized by a complex structure of elements can be found in the works of many authors (see: B. Berry, 1964, Z. Chojnicki, 1973, 1980; K. Dziewoński, 1972). Two different approaches can be traced in literature. One of them assumes that a settlement unit is sufficient to constitute a system (see: J. Regulski, 1980; W. Misiak, 1982), the other claims that a set of units is necessary (see: B. J. L. Berry, 1964; K. Dziewoński, 1972; R. Domański, 1980, Z. Chojnicki, 1980; Z. Rykiel, A'. Zurkowa, 1981). "If we assume a geographic viewpoint, we must agree that settlement systems are to be found on two levels of spatial organization: local and regional... Local settlement system is composed of a settlement unit..., regional settlement system consists of a set of units located on some territory" (see: Z. Chojnicki, 1980). City centres of different type and size are constitutive elements of the system of cities in Latin America. The system of cities is in turn a part of subsystem of another system i.e. of the spatial socio-economic system. Therefore the system of cities is environed by other sub-systems belonging to the spatial socio-economic system.

When the elements of the system are known, its structure becomes identifiable. The structure of the system is composed of a set of feedbacks between the elements of the system. Diversification and hierarchization of the cities are crucial for the structure of the system. Diversification of the phenomena in the system can be expressed as:

$$
\operatorname{St}(Z)=U\{\operatorname{St}(A): A \in Z\}
$$

where in order to describe the states of the phenomenon $\mathrm{Z}$ we use descriptions of its states in particular cases. A set of the states of system A, ordered as they occur in time is called a track of the system (see: R. Wójcicki, 1982).

Any system possesses some constant elements decisive for its persistence. In the system of cities they are centres with the highest probability to last. This can be attributed to such relations as:

- town settlement tradition in the region,

- its history,

- economic activity conducive or non-conducive to development,

- trends in location of the new towns. 
The research on the dynamics of the structure of a system should be primarily aimed at identification of its variable elements since they are decisive for its transformation. Another important task is to identify the hierarchy of its elements. It follows from the literature of the subject that an empirical system of the cities forms a hierarchical set (see: H. J. Milsum, 1976). But still it remains to check up if continuity of the internal hierarchical structure is maintained and if that pattern favours structural stability of the system, especially if it consists of a large number of diversified elements. As in any hierarchical, multilevel system, in the system of cities relations between particular elments are often antagonistic.

The performance of a system (its state or the pattern of transformation of its states) is influenced by changes in its environment. Conceptualizing the influence of environment on the system and vice versa, inputs and outputs of the system are distinguished. Variables $\mathrm{W}_{1}$ denote relations "environment - system", i.e. its inputs, while variables $V_{1}$ denote relations "system-environment", i.e. its outputs. With this in mind formula (2) is transformed into:

$$
A=W_{1}, \ldots, W_{k} ; \alpha, F_{1}, \ldots, F_{k} ; V_{1}, \ldots, V_{k} \text { ) }
$$

So variables $F_{i}$ are the internal variables of the system. while $W_{1}$ and $V_{1}$, the external ones. For the analysis of the system it is particularly important to know its inputs.

The amount of information derived from the system of cities is difficult to deal with in the research procedure. Therefore its principal task should consist in a proper selection of variables, i.e. of those which are crucial for the performance of the system. In the author's opinion the analysis of the system of cities in Latin America can be based on the following elements: geographical location, structure, functions (dominant economic activities), interactions (communications links and linkages of elements crucial for the city functions), zones (division into sub-systems).

Processes of change and reorganization of the system of cities in Latin America are primarily conditioned by such characteristics as: as:

(a) stabilized dynamics of the system: by the change in number, size and functions of its elements while the system remains internally integrated,

(b) structural change:

- change of the scope and type of relations between various elements and sub-systems, 
- change in the hierarchy of elements of the system,

(c) spatial evolution of the system,

(d) global evolution of the system.

\section{INTERNAL DIVERSIFICATION OF THE SYSTEM OF CITIES IN LATIN AMERICA}

Diversity of elements in the system of cities can be analysed along different lines. Population of a town has been a traditional criterion of classification. In the literature of the subject these are the most frequently listed sets of towns:

1. the set of metropolitan cities,

2. the set of very big towns with the population exceeding 500 thousand,

3. the set of big towns with the population ranging from 100 thousand to 500 thousand,

4. the set of medium towns with the population ranging from 20 thousand to 100 thousand,

5. the set of small towns with the population ranging from 5 to 20 thousand (the lower limit assumed differently for various countries ranges from 1.5 to 2.5 thousand).

The author will classify the elements of the system of cities in Latin America according to their respective roles in the development process of the whole system. Consequently, the following sets of the cities are distinguished:

A. The set of passive elements, frequentily of a long-lasting character, non-conducive to the internal change of the system. Among them are:

1. Pre-Columbian towns and those founded in the early period of the conquest. They had always been servicing very small regions and their relations with other towns had been quite limited (e.g.: the towns of South Mexico, Guatemala, the towns located in the mountains of Peru and Bolivia).

2. Ports and mining centres founded in the period of the Spanish colcinization; they were flowering in the 17-th and 18-th centuries. Exhaustion of mineral resources or destruction of a port sometimes brought about either a total decline of the city or caused its depopulation and degradation, while in other cases it stimulated a change of function, thus permitting it to survive until contemporary period. As a rule, those towns have been preserved in the system by force of tradition and their relations with other elements of the system are very limited (the towns of Middle Mexico, some Andean towns, 
a number of towns on the Caribbean coast).

3. The towns which in the colonial period were local administrative centres and had wide regional links. When old functions expired, the towns lost their importance.

4. Small local centres servicing the surrounding rural areas. External links are maintained with but a few similar centres and with one centre of regional significance.

$B$. The set of elements subject to change occurring within the system but incapable of dynamizing it. These elements of the system of cities are in various ways linked to the elements listed under $A$ and $C$ headings. The towns of this set tend to stabilize the system as a whole. They are also interrelated with the remaining sub-systems of the spatial socio-economic system. Here the following elements are included:

1. Regional centres related to local and national centres by a network of feedbacks:

- administrative centres of the first rank,

- old mining and industrial centres (founded before World War II),

- small and medium-sized nodal points of the transportation system (ports, centres built at the crossings of the traditional trade routes).

2. Local centres fulfilling specialized functions.

C. Most dynamic elements stimulating expansion of the whole system; they have a ramified network of feedback's with other elements of the system of cities and with elements of the systems constituting the environment of the system of cities.

1. Metropolitan areas,

2. Big industrial towns,

3. Big commercial towns,

4. The main service centres, especially the tourist ones.

D. New elements, capable of initiating deep structural change. Their role may prove crucial for evolution of the system and its direction.

1. The towns founded within the framework of the regional development policies pursued in a number of Latin-American countries, development poles being one example.

2. New town centres in the least developed zones (centres of the agricultural colonization, transportation junctions, strategic towns).

3. Old city centres receiving new development stimuli from the socio-economic system. Transformations that occur in the system of cities under the influence of elements $C$ and $D$ may involve a qualita- 
tive change of the whole system. To tell how much a town centre is liable to change, some of its properties must be assessed:

- the level utilization of its development potential (e.g.: the natural environment, the technical and the social potential),

- innovation receptiblity,

- spatial accessibility,

- adaptability - the ability to absorb change occurring in the entire system.

\section{THE IMPACT OF ENVIRONMENT ON THE SYSTEM}

The system of cities is related to its environment in many ways. Since we cannot deal with all the interactions, it is necessary to identify the main ones, those which enable the system to fulfill its integrative and adaptative functions, decisive for maintaining its stability. There are feedbacks between the system of cities and the economic, social, political and cultural systems. A change in any of those systems involves modifications of the system of cities. In Latin America it is affected by the economic, social, political and cultural phenomena among which the most important are:

1. Industrialization, intensified after World War II;

2. Growth of employment in the service sector;

3. Agricultural change, mainly development of the commercial cultures in many regions, as well as agricultural colonization of new lands;

4. Development of the transportation network - construction of the Pan-American Highway and the penetration roads in the river basins of the Amazon, Orinoco and in other regions;

5. Growth of population in the whole of Latin America;

6. Change in the population age-structure;

7. Rural overpopulation;

8. Growth of migrations after World War II, especially of the ruralurban ones;

9. Lack of political stability in many Latin-American countries , (frequent civil wars);

10. Repeated change of development strategies for political reasons;

11. Inadequete political division in the majority of the countries impedes economic integration;

12. Cultural dualism - traditional and modern cultures exist side by side;

13. Marked influence of the Spanish and Portuguese cultures and ways of life on the attitudes of individuals and entire social groups, coup- 
led with the parallel and growing influence of the North American patterns of behaviour and life styles.

14. Diverse aspirations and needs of inhabitants of particular regions.

Diverse interactions of the system of cities with other systems belonging to the spatial socio-economic system of Latin America result in a non-harmonious evolution of the former, i.e. some of its sub-systems change slower, while others quicker. Reorganization of the system of cities under the impact of the external stimuli may result in a greater self-integration of the system. Since the colonial times each of those stimuli has been specifically modyfying development and change within the system of cities.

Examination of the presented evolution of the system of cities in Latin America shows continuity of its development process, although its intensity varies from period to period. Phases of integration and decomposition can be clearly distinguished. The prepondering trend however, is towards integration of the system.

To sum up, we shall quote the most salient features of the historically produced system of cities in Latin America:

1. Regional and local models of the city network occurring in the system do not as a rule follow a classical hierarchical type; the networks of cities in Brazil and Colombia belong to but few exceptions. In most of the regions we find models with a marked domination of very big cities. (e.g.: in Argentina, Uruguay, Chile, Venezuela and Ecuador where two main cities dominate). Some areas represent the model in which medium-sized or big cities dominate, e.g. North Mexico, Sierra Region in Peru, the Greater Antilles. Dominance of very big cities is a general characteristics of the system.

2. Existence of many metropolitan areas with numerous supra-regional liniks. Rapid growth of those areas stands in a marked contrast with the slow progress of the remaining cities.

3. Slow growth or degradation of small and medium-sized towns.

4. Dynamic growth of population in big towns.

5. Lack of distinct specialization in most towns. The opposite is true for a relatively small group of towns. This conclusion is valid both for the system as a whole and for the regional sub-systems. 


\begin{tabular}{|c|c|c|c|}
\hline 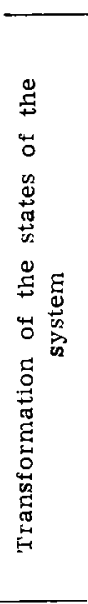 & 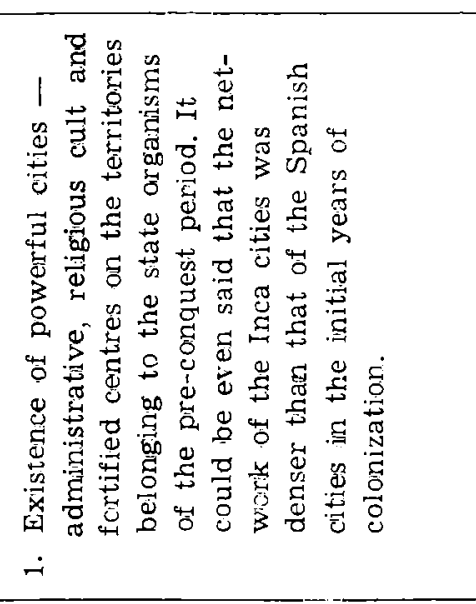 & 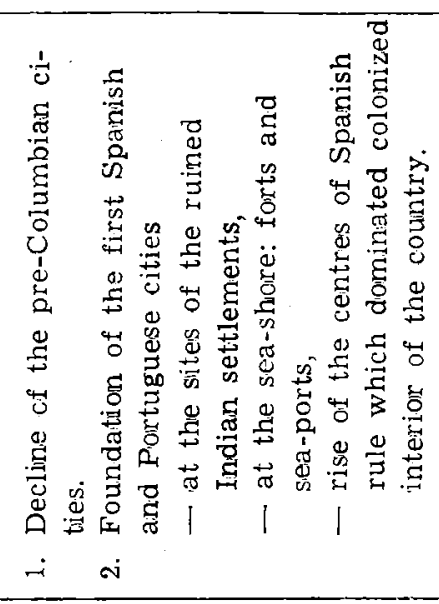 & 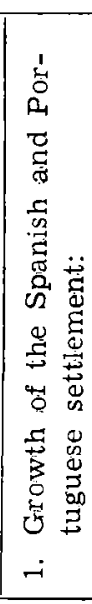 \\
\hline 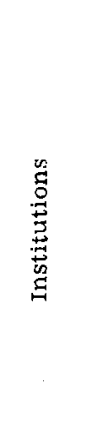 & 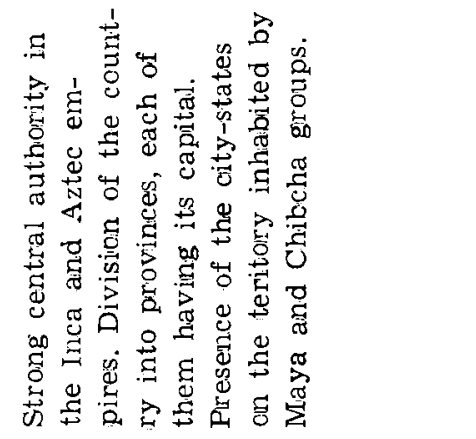 & 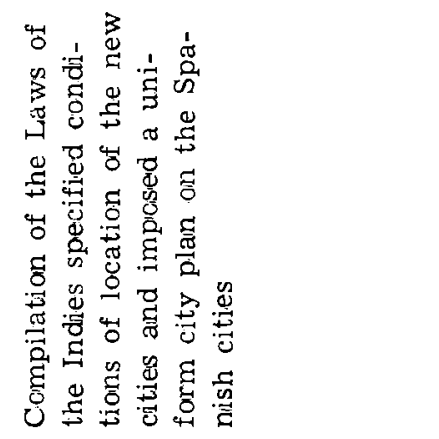 & 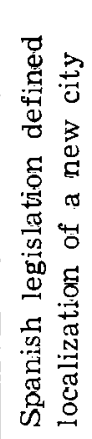 \\
\hline 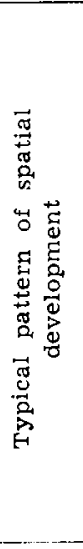 & 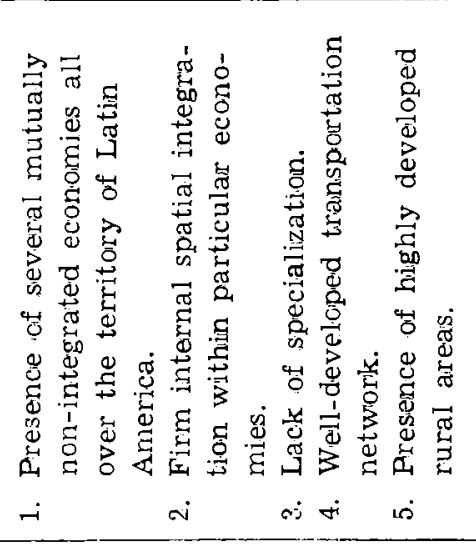 & 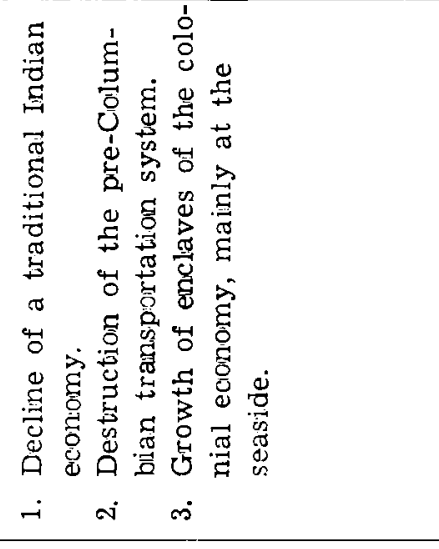 & 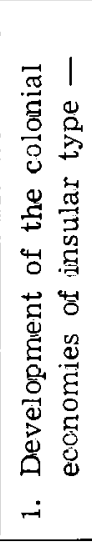 \\
\hline 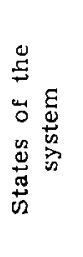 & 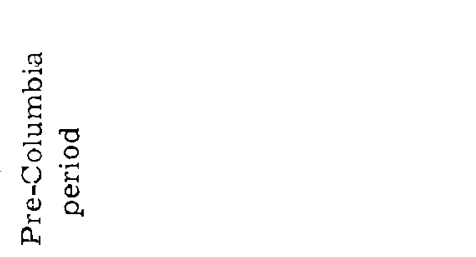 & 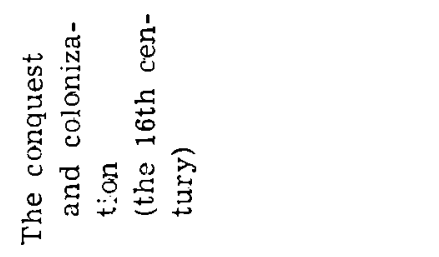 & 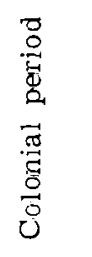 \\
\hline
\end{tabular}




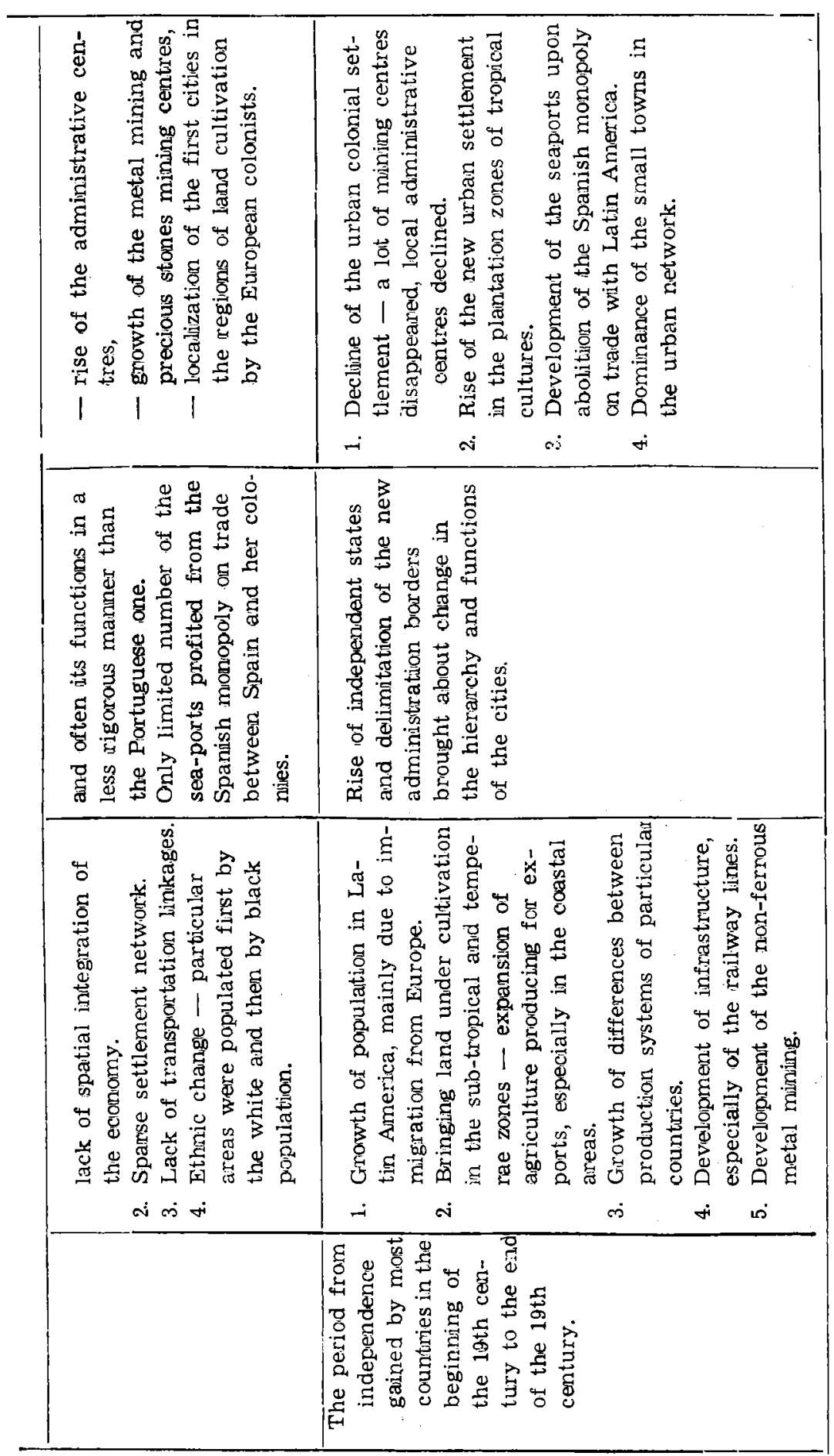




\begin{tabular}{|c|c|c|}
\hline 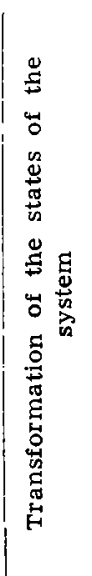 & 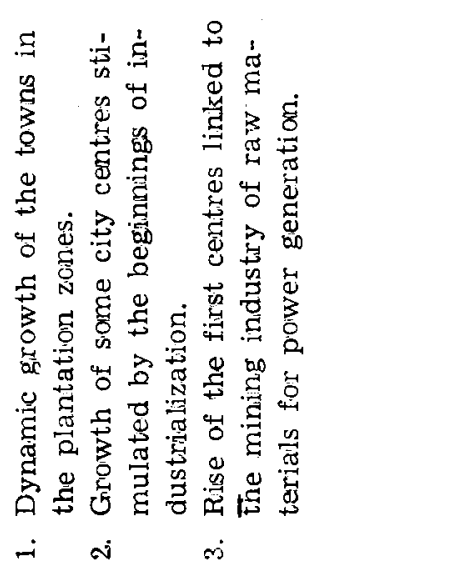 & 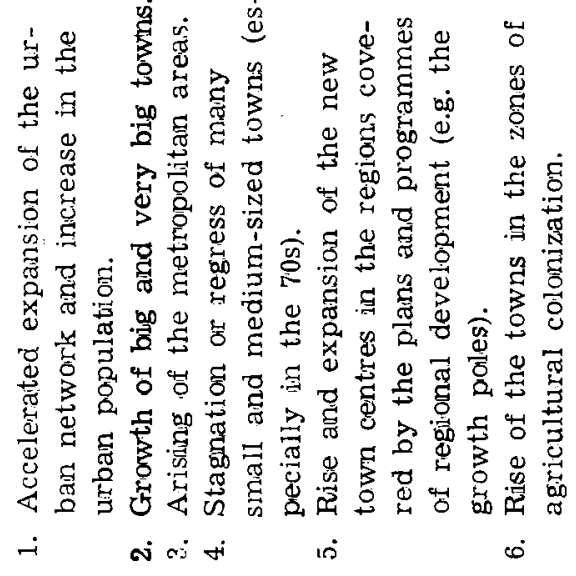 \\
\hline 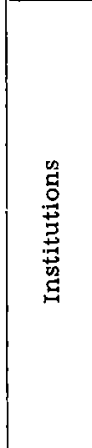 & 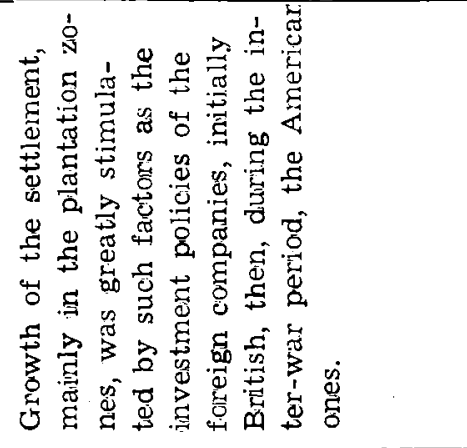 & 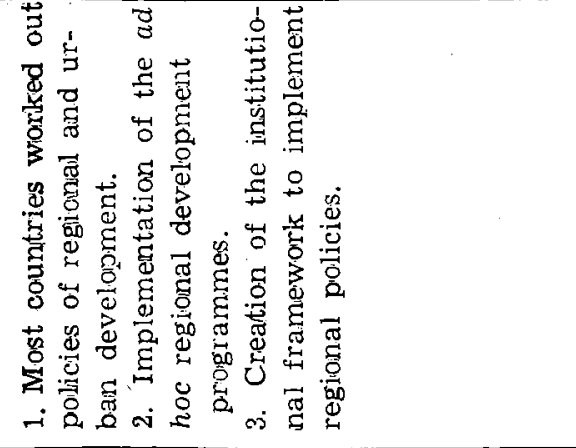 \\
\hline 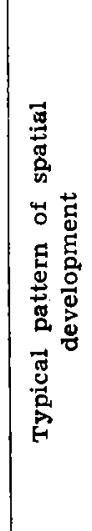 & 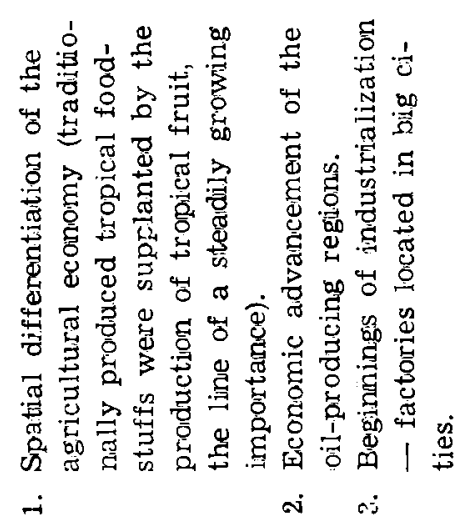 & 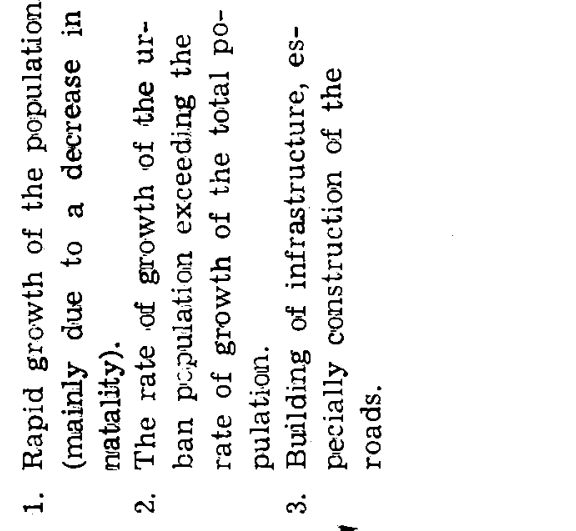 \\
\hline 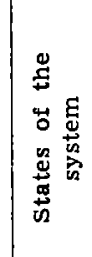 & 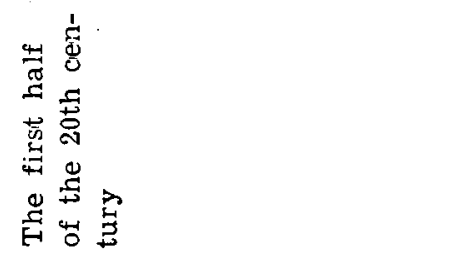 & 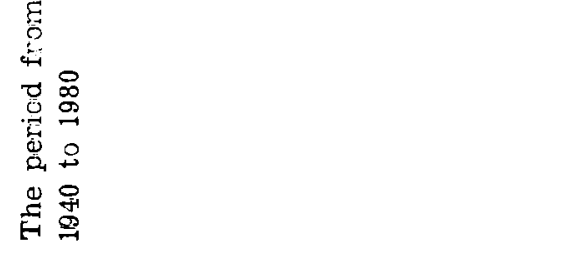 \\
\hline
\end{tabular}




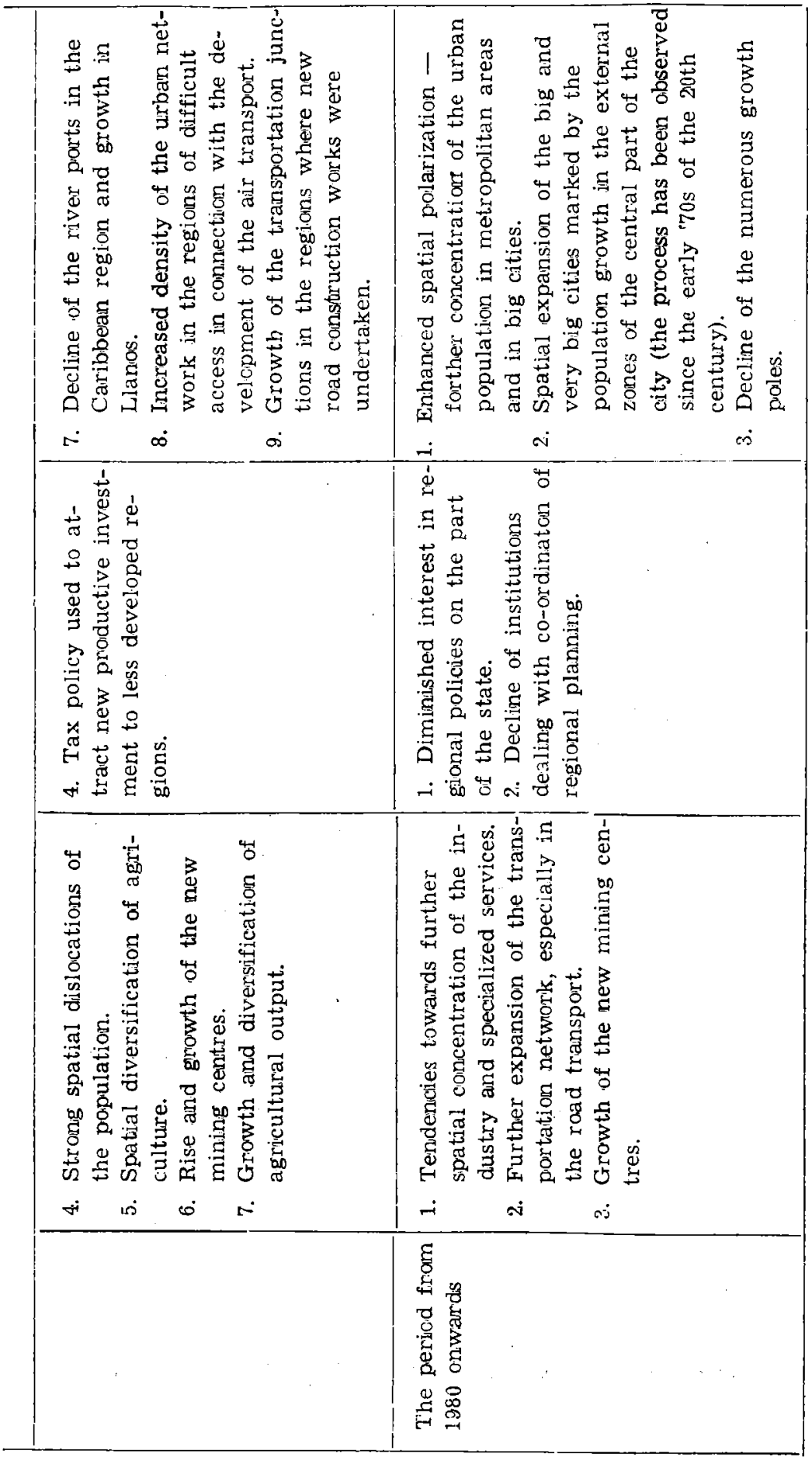




\section{BIBLIOGRAPHY}

Berry, B.J. L., "Cities as systems within systems of cities", in: Papers and Proceedings of the Regional Science Association, No. 10, 1964.

Chojnicki, Z., "Założenia i perspektywy rozwoju geografii ekonomicznej", (Assum.ptions and perspectives of development of the economic gography), Przeglad Geograficzny, Vol. 45, No. 1, 1973.

Chojnlicki, Z., "Podstawy metodologiczne prognozowania w geografii ekonomicznej", (Methodological foundations of forecasting in economic geography), Przeglqd Geografic zny, V.ol. 49, No. 2, 1977.

Chojnicki, Z., "Podstawy prognozowania regionalnych systemów osadniczych", (Foundations of fomecasting regional settlement systems), Przeglad Geograficzny, Vol. 52, N.o. 4, 1980.

Domański, R., "Zarys teorii procesów w systemie osadniczym", (An outline of a theory of the processes occurring in a settlement system), Przeglad Geograficzny, Vol. 48, No. 2, 1976.

Domański R., "Naczelne twierdzenie teorii rozwoju systemu osadniczego", (Principal proposition of the theory of development of a settlement system), Prze. glad Geograficzny, V.ol. 52, No. 4, 1980.

Domański, R., Teoretyczne podstawy geografii ekonomicznej, (Theoretical foundations of the economic geography), PWE, Warszawa 1982.

Dziewoński, K., "Przegląd teorii sieci osadniczej", (A review of the theories of the settlement network), in: Secomski, $K$. (ed.), Elementy teorii planowania przestrzennego (Elements of the theory of spatial planning), Committee for Space Economy and Regional Planning, PWN, Warszawa 1972.

Kmita, J., Wyklady $z$ logiki $i$ metodologii nauk, (Lectures in logic and methodology of sciences) PWN, Warszawa 1975.

Maik, W., "Założenia i zastosłowanie koncepcji zespolów osadniczych", (Assumptions and application of the concept of the settlement ensembles), Przeglad Geograficzny, Vol. 48, No. 2, 1976.

Milsum, H. J., "Podistawa hierarchiczna dla systemów agólnych żywych", in: Klir, G. J. (ed.), Trends in General Systems Theory, John Wiley and Sons Inc., New York 1972.

Misiak, W., "System kulturowy miasta uprzemysłowionego", (Cultural system of an industrialized city), Prace Wroclawskiego Towarzystwa Naukowego, Ossolineum, Wrocław 1982.

Regulski, J., Rozwój miast w Polsce, (Development of the cities in Poland), PWN, Warszawa 1980.

Rykiel, Z., Zuurkowa, A., Migracje między miastami: Systemy krajowe i regionalne (Inter-urban migrations: country systems and regional systems), in: Studia nad migracjami $i$ przemianami systemu osadniczego $w$ Polsce (Studies on migrations and changes of the settlement system in Poland), Prace Geograficzne, Institute of Geography and Space Economy of the Polish Academy of Sciences, Warszawa 1981.

Sadowski, W., Podstawy ogólnej teorii systemów. Analiza logiczno-metodologiczna, (Foundations of a general theory of the systems. Logico-methodiological analysis), (translated from Russian), PWN, Warszawa 1978.

Wójcicki R., Wykłady $z$ metodologii nauk, (Lectures in methodology of sciences), PWN 1982. 